\title{
Genetic Analysis of Yield Components and Physiological Characters under Changing Climate in Wheat
}

\author{
Akanksha Tiwari*, D.K. Mishra and R.S. Shukla \\ Department of Plant Breeding and Genetics, JNKVV, Jabalpur (MP), India \\ *Corresponding author
}

\author{
A B S T R A C T
}

\begin{tabular}{|l|}
\hline Ke y w o r d s \\
GCV, PCV, \\
Heritability. \\
Genetic advance, \\
Wheat. \\
\hline Article Info \\
\hline $\begin{array}{l}\text { Accepted: } \\
\text { 10 July 2017 } \\
\text { Available Online: } \\
\text { 10 September } 2017\end{array}$ \\
\hline
\end{tabular}

The changing climate adversely affect the morphological characters of plant which, ultimate effect the identification of off types in seed production programme. This also leads to effect the genetic purity in seed production programme. To overcome this problem selection of progeny and its breeding depend upon the genetic variability in population. Fourteen varieties of wheat and their forty crosses were evaluated in randomized block design (RBD) with three replications for yield components and physiological traits during rabi 2015-16, to find out genetic variability, heritability and genetic advance percent of mean. Significant genetic differences were observed for all the quantitative characters studied, indicating considerable amount of variation among genotypes. Moderate genotypic and phenotypic coefficient of variation exhibited by grain yield per plant, biological yield per plant, ear weight, number of ears per plant, peduncle length and sedimentation value while, number of tillers per plant and harvest index showed moderate PCV but low GCV. All of the traits expressed high heritability. However, biological yield per plant and sedimentation value showed high and moderate genetic advance, respectively which, indicates that the heritability is most likely due to additive gene effect and selection may be effective for these traits. It is also observed that the performance of these characters is not under influence of environment. However, other characters might be effected by the change in climatic condition. Thus, in seed production programme at the time of rouging these characters must be considered to maintain the genetic purity of seed.

\section{Introduction}

The changing climate adversely affect the morphological characters of plant which, ultimate effect the identification of off types in seed production programme. This also leads to affect the genetic purity in seed production programme. To overcome this problem selection of progeny and its breeding depend upon the genetic variability in population. Wheat (Triticum aestivum L.) is the first important and strategic cereal crop for the majority of world's populations. It is the most important staple food of about two billion people (36\% of the world population). Selection of progeny and its breeding depend upon the genetic variability in population. The extent of genetic variability has been considered as an important factor which is an essential pre-requisite for a successful hybridization aimed at producing high yielding progenies. The knowledge of heritability helps the plant breeder in predicting the behaviour of the succeeding 
generations, making desirable selection and assessing the magnitude of genetic improvement through selection. Higher estimates of heritability coupled with better genetic advance confirm the scope of selection in developing new genotypes with desirable characteristics. Hence, heritability estimates in this study would help to predict about the possible progress that can be attained by making the selection process effective. Moreover, genetic advance estimates give a clear picture of $F_{1}$ generation to make selection effective. This study is aimed to estimate variability and genetic parameters for yield components and physiological characters. These values will help in making effective selection under variable environmental conditions for the improvement of characters under study.

\section{Materials and Methods}

The experimental material was comprised of forty $F_{1}$ populations involving 14 selected genotypes as parents: GW-273, GW-322, GW-366, JW-1201，JW-1202，JW-1203, LOK-1, HD-2864, HD-2932, HI-1544, JW3336, JW-3288, MP-3269, JW-3211. The experiment was carried out under Wheat Improvement Project, Department of Genetics and Plant Breeding at Seed Breeding Farm, College of Agriculture, Jawaharlal Nehru Krishi Vishwa Vidyalaya, Jabalpur (M.P) during rabi 2015-16. The $F_{1}$ Seeds and parents were grown in lines keeping plant to plant distance at $10 \mathrm{~cm}$ and row to row distance at $20 \mathrm{~cm}$. All the crop protection measures were adopted on time. Data were collected for Days to $50 \%$ heading, Days to maturity, plant height, Number of tillers per plant, Number of spikelets per ear, Ear length (cm), Ear weight, Number of ears per plant, peduncle length, Number of grains per ear, 1000-grain weight, Biological yield per plant, Grain yield per plant, Harvest index, Canopy temperature, Chlorophyll content. At maturity, five healthy and competitive plants from the each $F_{1}$ cross and each parent were taken at random and data were recorded and analyzed. The analysis of variances suggested by Burton (1952), heritability in broad sense (h2bs) is suggested by Hanson et al. (1950) and genetic advance (GA) was estimated by Johnson et al. (1955). Mean sums of square were calculated as indicated in Table 1.

\section{Results and Discussion}

To know the extent of variation for observed characters among the genotypes of wheat, analysis of variance was performed and presented in table 1. Results of analysis of variance indicated that the mean sums of squares due to genotypes were highly significant for all the traits under study, suggesting presence of sufficient variation among the genotypes for these traits. Maximum variability was observed for biological yield per plant (472.75) while, minimum for ear weight (0.65). The magnitude of variability in decreasing order for other traits were as follows: sedimentation value, number of grains per ear, grain yield per plant, chlorophyll content, plant height, peduncle length, 1000-grain weight, wet gluten, harvest index, days to maturity, number of ears per plant, days to $50 \%$ heading, canopy temperature, number of spikelets per ear, starch content, protein content, number of tillers per plant, ear length and ear weight. The variability among parental lines and $F_{1} s$ ranged from biological yield per plant to ear weight. This was in conformity with the findings of Ahmed et al. (2015), Ali et al. (2008), (Singh et al. 2015).

Mean and range performance for yield component characters are summarized in table 2. The character days to $50 \%$ flowering ranged from 66.00 to 73.66 days with an average of 70.42 days. Days to maturity varied from 113.33 to 122.66 days with mean of 117.81 days. 
Table.1 Analysis of variance for yield and yield attributing traits

\begin{tabular}{|c|c|c|c|c|c|c|c|c|c|c|c|}
\hline \multirow[b]{2}{*}{ S.V. } & \multirow[b]{2}{*}{ D.F. } & \multicolumn{10}{|c|}{ Mean sums of squares } \\
\hline & & $\begin{array}{c}\text { Days to } \\
50 \% \\
\text { Flowering }\end{array}$ & $\begin{array}{c}\text { Days to } \\
\text { Maturity }\end{array}$ & $\begin{array}{c}\text { Plant } \\
\text { Height }\end{array}$ & $\begin{array}{c}\text { Tillers/ } \\
\text { Plant }\end{array}$ & $\begin{array}{c}\text { Spikelets/ } \\
\text { Ear }\end{array}$ & $\begin{array}{c}\text { Ear } \\
\text { Length }\end{array}$ & $\begin{array}{c}\text { Ear } \\
\text { Weight }\end{array}$ & $\begin{array}{c}\text { Peduncle } \\
\text { Length }\end{array}$ & $\begin{array}{l}\text { Ears/ } \\
\text { Plant }\end{array}$ & $\begin{array}{c}\text { Grains/ } \\
\text { Ear }\end{array}$ \\
\hline Replicate & 2 & 3.081 & 0.11 & 0.67 & 0.12 & 0.02 & 0.01 & 0.00 & 1.34 & 0.10 & 0.22 \\
\hline Treatments & 53 & $11.86 * *$ & $20.39 * *$ & $38.71 * *$ & $3.18 * *$ & $6.05 * *$ & $2.43 * *$ & $0.65 * *$ & $33.38 * *$ & $12.03 * *$ & $72.97 * *$ \\
\hline Error & 106 & 2.02 & 1.63 & 1.09 & 0.65 & 0.51 & 0.19 & 0.07 & 1.53 & 0.52 & 2.31 \\
\hline
\end{tabular}

\begin{tabular}{|c|c|c|c|c|c|c|c|c|c|c|c|}
\hline \multirow[b]{2}{*}{ S.V. } & \multirow[b]{2}{*}{ D.F. } & \multicolumn{10}{|c|}{ Mean sums of squares } \\
\hline & & $\begin{array}{c}\text { 1000- } \\
\text { grain } \\
\text { Weight }\end{array}$ & $\begin{array}{c}\text { Biological } \\
\text { Yield/ } \\
\text { Plant }\end{array}$ & $\begin{array}{l}\text { Grain } \\
\text { Yield/ } \\
\text { Plant }\end{array}$ & $\begin{array}{l}\text { harvest } \\
\text { Index }\end{array}$ & $\begin{array}{c}\text { Canopy } \\
\text { Temperature }\end{array}$ & $\begin{array}{l}\text { Chlorophyll } \\
\text { Content }\end{array}$ & $\begin{array}{l}\text { Sedimenta- } \\
\text { tion Value }\end{array}$ & $\begin{array}{l}\text { Protein } \\
\text { Content }\end{array}$ & $\begin{array}{c}\text { Wet } \\
\text { Gluten }\end{array}$ & $\begin{array}{l}\text { Starch } \\
\text { Content }\end{array}$ \\
\hline Replicate & 2 & 1.66 & 9.11 & 0.37 & 4.44 & 1.16 & 2.19 & 0.20 & 0.01 & 0.16 & 0.04 \\
\hline Treatments & 53 & $32.46 * *$ & $472.75 * *$ & $54.91 * *$ & $31.58 * *$ & $7.61 * *$ & $48.23 * *$ & $124.69 * *$ & $3.29 * *$ & $31.96 * *$ & $5.99 * *$ \\
\hline Error & 106 & 0.56 & 4.94 & 1.03 & 1.45 & 0.38 & 0.74 & 0.28 & 0.01 & 0.47 & 0.27 \\
\hline
\end{tabular}

\footnotetext{
$*$,** indicates significance at $5 \%$ and $1 \%$ probability level, respectively.
} 
Table. 2 Genetic parameters of variability for yield and yield attributing traits in wheat

\begin{tabular}{|c|c|c|c|c|c|c|c|}
\hline \multirow[t]{2}{*}{ Characters } & \multirow[t]{2}{*}{ Grand mean } & \multicolumn{2}{|c|}{ Range } & \multicolumn{2}{|c|}{$\begin{array}{c}\text { Coefficient of } \\
\text { variation }\end{array}$} & \multirow[t]{2}{*}{$\mathbf{H}^{2}(\mathrm{BS})$} & \multirow[t]{2}{*}{ GA as per cent of mean } \\
\hline & & Min & Max & GCV & PCV & & \\
\hline Days to $50 \%$ heading & 70.42 & 66.00 & 73.66 & 2.57 & 3.27 & 62 & 2.93 \\
\hline Days to maturity & 117.81 & 113.33 & 122.66 & 2.12 & 2.38 & 79 & 4.59 \\
\hline Plant height & 76.21 & 66.30 & 85.00 & 4.65 & 4.85 & 92 & 6.99 \\
\hline Tillers/plant & 13.97 & 11.56 & 16.81 & 14.02 & 14.94 & 88 & 3.78 \\
\hline Spikelets/ ear & 19.20 & 16.32 & 22.20 & 7.08 & 8.00 & 78 & 2.48 \\
\hline Ear length & 11.07 & 9.07 & 13.05 & 7.81 & 8.77 & 79 & 1.59 \\
\hline Ear weight & 3.29 & 2.33 & 4.20 & 13.48 & 15.70 & 74 & 0.78 \\
\hline Peduncle length & 25.98 & 16.29 & 31.28 & 12.54 & 13.42 & 87 & 6.27 \\
\hline Ears/plant & 11.41 & 9.5 & 13.9 & 8.05 & 10.72 & 56 & 1.42 \\
\hline Grains/ear & 56.29 & 43.89 & 64.48 & 8.62 & 9.04 & 91 & 9.54 \\
\hline 1000-grain weight & 38.18 & 32.96 & 44.00 & 8.54 & 8.76 & 95 & 6.55 \\
\hline Biological yield/plant & 67.10 & 46.29 & 94.10 & 18.61 & 18.90 & 97 & 25.33 \\
\hline Grain yield/plant & 22.42 & 13.55 & 30.15 & 18.90 & 19.44 & 95 & 8.49 \\
\hline Harvest index & 33.49 & 28.99 & 42.61 & 9.46 & 10.12 & 87 & 6.10 \\
\hline Canopy temperature & 19.03 & 15.82 & 21.30 & 8.16 & 8.77 & 86 & 2.97 \\
\hline Chlorophyll content & 42.84 & 35.64 & 51.91 & 9.29 & 9.50 & 96 & 8.01 \\
\hline Sedimentation value & 49.32 & 30.60 & 61.90 & 13.06 & 13.10 & 99 & 13.22 \\
\hline Protein content & 12.91 & 10.06 & 14.90 & 8.10 & 8.13 & 99 & 2.15 \\
\hline Wet gluten & 36.14 & 27.36 & 41.46 & 8.96 & 9.16 & 96 & 6.53 \\
\hline Starch content & 64.41 & 60.46 & 66.66 & 2.19 & 2.20 & 99 & 2.88 \\
\hline
\end{tabular}


Among the parents, genotype GW 273 (Line) and JW 3288 (Tester were earliest in maturity, while HD 2932 (Line) and JW 3211 (Tester) matured late. Whereas, among the hybrids, GW 273 X JW 3336 was earliest in maturity, while HD 2864 X MP 3269 matured late. The degree of dispersion for the plant height ranged between 66.30 to $85.00 \mathrm{~cm}$. with an average performance of $76.21 \mathrm{~cm}$. Number of tillers per plant had an average performance of 13.97 with a range of 11.57 to 26.81. Number of spikelets per ear was recorded in the range of 16.32 to 22.20 with an average at 19.20. Ear length varied from $9.07 \mathrm{~cm}$ to $13.05 \mathrm{~cm}$ with a mean of 11.07 $\mathrm{cm}$. Ear weight ranged from $2.33 \mathrm{~g}$ to $4.20 \mathrm{~g}$ with a mean of $3.29 \mathrm{~g}$. Peduncle length has an average of $25.98 \mathrm{~cm}$ with a minimum of $16.30 \mathrm{~cm}$ and maximum $31.28 \mathrm{~cm}$. Number of ears per plant showed a mean value 11.41 and varied from 9.53 to 13.97. Number of grains per ear showed a variation ranging from 43.90 to 64.48 with a mean value of 56.29. 1000grain weight recorded a minimum value of $32.97 \mathrm{~g}$ and a maximum of $44.00 \mathrm{~g}$ with a mean value of $38.18 \mathrm{~g}$. Range of variation observed for biological yield per plant was $46.30 \mathrm{~g}$ to $94.11 \mathrm{~g}$ with mean value of 67.10 g. Grain yield per plant recorded a minimum value of $13.56 \mathrm{~g}$ and a maximum of $30.15 \mathrm{~g}$ with a mean value of $22.42 \mathrm{~g}$. Harvest index showed a variation ranging from $28.99 \%$ to $42.62 \%$ with a mean value of $33.49 \%$. Range of variation observed for canopy temperature trait was 15.82 to 21.30 with mean value of 19.03 .

Phenotypic coefficients of variation estimates were higher than the genotypic coefficients of variation for all characters under study. Grain yield per plant recorded the moderate PCV (19.44) and GCV (18.90) followed by biological yield per plant $(18.90,18.61)$; ear weight $(15.70,13.48)$; number of tillers per plant $(14.94,14.02)$; peduncle length (13.42, 12.54); sedimentation value $(13.10,13.06)$.
Number of ears per plant $(10.72 \%, 8.05 \%)$ and harvest index $(10.12 \%, 9.46 \%)$ showed moderate PCV but low GCV, respectivey. Similar findings were also reported by Ghimiray and Sarkar (2000), Tripathi et al. (2009) and Bisht and Gahalain (2009).

Heritability and genetic advance are important selection parameters. Heritability estimate along with genetic advance are normally more helpful in predicting the gain under selection than heritability alone. However, it is not necessary that a character showing high heritability will also exhibit high genetic advance. Results showed that all the characters expressed high estimates of heritability except number of tillers per plant $(56.31 \%)$. It indicates that the heritability is most likely due to additive gene effect and selection may be effective. The high genetic advance as percentage of mean was showed by biological yield per plant $(25.33 \%)$. However, moderate genetic advance was recorded for sedimentation value (13.22\%). In this study high heritability with high genetic advance was observed for biological yield per plant and high heritability with moderate genetic advance was also observed for sedimentation value indicated predominance of additive gene action for controlling these characters. Thus, simple selection can be practiced to improve these characters. This was in consonance with the findings of Fikre et al. (2015), Hassan et al. (2013) and Fellahi et al. (2013).

It is concluded from these study that characters like biological yield per plant and sedimentation value are not under influence of environment. However, other characters might be affected by the change in climatic condition. Thus, in seed production progrmme at the time of roguing these characters must be considered to maintain the genetic purity of seed. 


\section{References}

Ahmed HGM, Saddam MS., Khan A, Fatima A., Saleem S, Hassan M., Zahid S, Benish M. 2015. Genetic mechanisms of yield related morphological markers response to increase grain yield in different environment of hexaploid wheat. Journal of Biodiversity and Environmental Sciences 6(3): 158-164.

Ajmal SU, Sohail K, Saleem M and Haq MI. 2000. Association analysis for grain yield and yield components in maize. Pakistan Journal of Plant Science 6: 12-17

Ali Y, Atta BM, Akhter J, Monneveux P and Lateef Z. 2008. Genetic variability, association and diversity studies in wheat (Triticum aestivum L.) germplasm. Pakistan Journal of Botany 40(5): 2087-2097.

Bakshi SMA, Barai BK, Murmu K. 2008. Genetic variability inwheat (Triticum aestivum L) under new alluvial zoneof West Bengal. Environment and Ecology 26(1):58-60.

Baranwal DK, Mishra VK, Vishwakarama MK, Yadav PS and Arun B. 2012. Studies on genetic variability, correlation and path analysis for yield and yield contributing traits in wheat (Triticum. aestivum L. em Thell). Plant Archives 99-104.

Bisht, Deepti, and Gahalain S S. 2009. Study on Genetic Variability in Wheat Germplasm grown in Hills of Uttarakhand. Vegetos 22(1)

Burton GW. 1952. Quantitative inheritance in grasses. Proceedings of 6th International Grassland Congress 1: 127 - 83.

Fellahi Z, Hannachi A, Guendouz A, Bouzerzour H and Boutekrabt A. 2013. Genetic variability, heritability and association studies in bread wheat (Triticum aestivum L.) genotypes. Electronic J. Plant Breeding, 4(2): 1161-1166.

Fikre G, Alamerew S, Tadesse Z. 2015. Genetic Variability Studies in Bread Wheat (Triticum aestivum L.) Genotypes at Kulumsa Agricultural Research Center, South East
Ethiopia. Journal of Biology, Agriculture and Healthcare 5(7): 89-98.

Ghimiray TS and Sarkar KK. 2000. Estimation of genetic parameters of some quantitative traits in wheat (Triticum aestivum L.) grown in Terai soils of West Bengal. Environment and Ecology 18(2): 338-340.

Hanson WD, Robinson HF and Comstock RE. 1956. Biometrical studies of yield segregating population Korean lespandeza. Agron. J., 48:268-272.

Hassan MS, El-Said RAR and Abd-El-Haleem SHM. 2013. Estimation of Heritability and Variance Components for Some Quantitative Traits in Bread Wheat (Triticum aestivum L.). World Applied Sciences Journal 27 (8): 944949.

Hokrani, VK, Rudranaik, V, Nadaf HL, Desai SA, Deshpande SK, Kalappanavar IK and Patil BN. 2013. Genetic studies in free threshable advanced segregating population of tetraploid wheat (Triticum diccocum). Karnataka Journal of Agriculture Science 26(1): 10-13.

Johnson HW, Robinson HF and Comstock RE. 1955. Estimate of genetic and environmental variability in soybean. Agron. J., 47: 314-318.

Singh J, Chawla V, Garg P, Gupta M and Chugh LK. 2015. Correlation and path analysis in advanced lines of wheat (Triticum aestivum $\mathrm{L}$. em. Thell). Indian Res. J. Genet. and Biotech 7(1): 22-26.

Tayyar S. (2008). Grain yield and agronomic characteristics of Romanian bread wheat varieties under the conditions of Northwestern Turkey. African Journal of Biotechnology 7(10):1479-1486

Tripathi V, Parasuraman B, Laxmi A, Chattopadhyay D. 2009. CIPK6, a CBLinteracting protein kinase is required for development and salt tolerance in plants. The Plant Journal. 58: 778-790.

\section{How to cite this article:}

Akanksha Tiwari, D.K. Mishra and Shukla, R.S. 2017. Genetic Analysis of Yield Components and Physiological Characters under Changing Climate in Wheat. Int.J.Curr.Microbiol.App.Sci. 6(9): 3525-3530. doi: https://doi.org/10.20546/ijcmas.2017.609.433 